\title{
Musica Practica According to Roland Barthes
}

\author{
Jozef Cseres / 114731@mail.muni.cz \\ Department of Musicology, Faculty of Arts, Masaryk University, Brno, CZ
}

\begin{abstract}
The contribution deals with Roland Barthes' musical aesthetics, with his dichotomous view of music - the manual or muscular ("the music one listens to") on the one hand, and the liquid or effusive ("the music one plays") on the other. Barthes grasped these as two different arts, each with its own history, its own sociology, its own aesthetics, and its own erotic. The first one, driven by desire, represents an amateurish music-making, the second one, played by professional musicians by heart, represents a professional musical praxis. Amateur music is characterized by intimate contact of the musician's body and his/her art. The aim of the paper is to explore both musics in the context of actual musical thought and post-Cagean ways of music making and listening.
\end{abstract}

\section{Keywords}

Roland Barthes, music, aesthetics, listening, gesture, performance, rhythm, Musica Elettronica Viva 
Since the times of Boethius, who resuscitated the Phytagorean-Platonic vision of harmonia mundi, till the late $18^{\text {th }}$ century, the artifactuality (artificium) was considered for a low-grade (= less symbolical) aspect of music making. Though musica instrumentalis (or instrumentis), created by human hands, was the only audible music among the artes liberales, it was less valuable than inaudible musica mundana and musica humana, created by the human mind. Later on, after major changes in European musical thought in early $17^{\text {th }}$ century, a quite different situation evolved gradually in the music world leading to the alienated relationship between an author and his/her work and to the overvalued status of a performer. The aforementioned scheme and further music development resulted in speculative oppositions "musica naturalis vs. musica artificialis" and "composed music vs. improvised music", both sustained and nourished by the institutional mechanisms of the music world.

The situation started to change in the 1960s when the late avant-gardists as well as the poststructuralist thinkers doubted the taxonomic schemes prevailing in music theory and practice and they focused on the listener. The concepts of "work in progress", "attentive listening" (John Cage), “opera aperta” (Umberto Eco), "death of the author" (Roland Barthes), "noise" (Jacques Attali), etc. were born and applied also to actual music. Aesthetics of music fused with philosophy and sociology in order to reveal the hidden mechanisms and powers of music production. No more new music but a new way of music-making and listening to music! Jacques Attali announced the advent of a network of composition with new types of relationships between musician, sound medium and society; musician makes music for pleasure caused by producing the sound differences. The new way of making music will re-establish our broken and deformed relationships to the world and others and it will give them new meaning, deprived of old codes and alienation between the author, performer and the listener. This kind of music should transform a listener into an "operator" - just like Roland Barthes imagined.

Barthes, himself an amateurish pianist, was obsessed with music but unlike Attali who utilized music as a means of his own theorizing, he used his own musical experience to reveal those characteristics of texts (works, pieces) that theory avoided or even destroyed. Trying to soften a strictness of structural method and suppress his own "structural reflex", Barthes began to dissolve the semiological differences in the aesthetic-erotic discourse that shouldn't be political nor religious nor scientific, but it should complement all these discourses. He imagined how the "astonishing science of language effects" will absorb a scholar himself. This kind of attitude also allowed him to deal meaningfully with the deconstructive practices of avant-garde art.

But in music Barthes applied this attitude only to a limited extent; as he would have his hands bound by his own musical experience. He was aware of the fact that we not only hear (physiologically) but also listen (psychologically) to the sounds around us. To hear and to listen to are two different processes. He distinguished between three types of listening - alert (listening to the indices), deciphering (listening to the signs), and inter-subjective (listening to the causer of sounds/speech). In mutual interactivity, three different types of listening contribute to the transformation of an undifferenced 
sound reality into a meaningful cultural "trophy": "By her noises, Nature shudders with meaning." 1

Barthes even listened to writing, having called this exciting activity "writing aloud". In that manner he rehabilitated a corporality of human voice and gestures in vocal and musical performance. Though he based his argumentation on the analysis of the voices of classical opera singers and his own piano playing, advocating a larynx and muscularity he was more instrumental for the phonic poets, performance and conceptual artists working on the frontier of language, utterance, text and image. Gesturality is extremely important in music, too; music is in a way immune against significance, it cannot be identified with significance. Music is polysemical but this does not mean that it has more coexisting meanings; music is simply a kind of overbridging for pulsing plural meaning that resists exact interpretations. Where once Claude Lévi-Strauss found the combinable elements of structures, Roland Barthes met the singularities describable only in metaphors.

For him only two musics existed: "one you listen to" and "one you play". ${ }^{2}$ He grasped them as two "entirely different arts, each with its own history, sociology, aesthetics, erotics: the same composer can be minor when listened to, enormous when played (even poorly)." ${ }^{3}$ He called the first music manual or muscular, the second one liquid or effusive. The first one is the domain of amateurish music playing, the second one of professional praxis. The first one is driven by desire, the second one by satisfaction. We play the first one from the heart, the second is performed by professionals by heart. It is this high evaluated amateurism for which the intimate contact between body of musician and his/her art is typical. The physical limits of his own piano playing inspired Barthes to aestheticize and signify the unpredictable and non-transferable imperfections and peculiarities of music performance that critique denounces or, in better cases, downplays or overlooks. Barthes' passionate attitude towards amateurism also suited Jacques Attali and it is quite probable that his revision of the history of music production was partly inspired by Barthes' concept of amateurism.

However, the musician, especially the amateurish one, does not play only from the heart and brain but also from his/her body (no matter if his/her own music or the music of others). The correspondences between body and music are audible thanks to the pulsing rhythms. Pulsation is a criterion of music's authenticity. But pulsation goes beyond musical means, it involves a naturally inherited bodily rhythm (of heart, breath, blood circulation, stretching of muscles, bending of knuckles) that the professionals use to supress and replace by trained techniques, rhetoric figures and learned phrasing. In so doing they kill a passion by artificial virtuosity. The pulsation grasped in a Barthesian way is an organic compound of impulse, rhythm, drive, force, vitality and passion. It is affective and though ungraspable in conventional metre-rhythmical measures neither reducible to sensomotoric movements. Barthes observed also the difference between

1 BARTHES, Roland. The Responsibility of Forms. Critical Essays on Music, Art, and Representation. Berkeley/ Los Angeles: University of California Press, 1991, p. 250.

2 Ibidem, p. 261.

3 Ibidem. 
a deep rhythm of ancient, authentic culture (asceticism/festivity) and a "banal rhythm of modernity" (work/free time). He searched for this rhythm in his life and tried to live according to it. It was an irregular rhythm; its refrains weren't repeated mechanically, they were determined by pure becomings that Barthes was able to signify and enjoy with pleasure. He felt intuitively what Gilles Deleuze and Félix Guattari genially formulated soon after him - that the relationship between world and music is not mechanical or mathematical but rhythmic and machine-like.

\section{$\mathbf{x} \times \mathbf{X} \times$}

Soon after I wrote and delivered the above paper, I witnessed a unique performance by Musica Elettronica Viva (MEV) at the Brno Philharmonic Hall. MEV is a legendary group that significantly contributed to the paradigmatic changes in Euro-American musical thought. It was founded in 1966 in Rome by Alvin Curran, Frederic Rzewski and Richard Teitelbaum who began there as young adepts of composition with brave ambition to deprive its hegemony in the music world and replace it with more actual and more meaningful music-making without generic and genre limits. After collective improvisation in real time became the group's main poetical principle, its members integrated modern live electronics that replaced past and alienated tape music. They renounced a precisely notated music having melted elitist composing in the "comprovisations" freed of any musical traditions except sound making as archaic means of expression. Rzewski accurately formulated the poetics of MEV by the witty slogan "form for music that has no form," Curran likened its members to "experimental archaeologists who reconstruct the origins of human music." Unlike "archaeology of knowledge" promoted by Michel Foucault, the archaeology provided by MEV does not search for the hidden mechanisms and conceptual limits of discursive knowledge (épistémè), MEV rather emphasizes and explores archetypal music making of forgotten times "when noise, breath, speech and music were all the same“ what Curran calls a "neo-primitive essentialism". ${ }^{4}$ In every moment of their performance the members of MEV collectively deconstruct the possibility of pure medium being aware that all media are mixed because they are inseparable from gestures - the mental as well as physical ones - that precede them.

And so, the integral musical gesturalism of MEV naturally includes the music's relations to physicality, memory, environment, society, as well as to technology and politics. MEV makes music with conviction that rather than to be an elitist art, music is an anthropological constant, symbolic form reflecting the correspondences between human beings (musicians as well as their listeners) and the natural and social environment where they live and which they influence and help to form through their musicmaking. The music of MEV is therefore very physical; it starts, lasts and ends with gestures. The members of the group do not play it only from the heart and mind but also from their bodies. It pulses in irregular rhythms determined by pure becomings.

4 CURRAN, Alvin. Shofar Rags. In: Shofar Rags (CD booklet). Zorn, John (ed.). New York: Tzadik, 2013, p. 2-4. 
It is the Music that sustains a human as a social being. „Music - some kind of socially purposeful resonating of objects and people - is the one human activity which provides (without any guarantee) that by becoming sound we can and do momentarily disappear into an unnameable space of ecstatic potential. " 5 Simply, musica practica in full effect of existential and experiential spacetime.

\section{Bibliography}

ATTALI, Jacques. Noise. The Political Economy of Music. Minneapolis/London: The University of Minnesota Press, 2002. English translation: Brain Massumi.

BARTHES, Roland. The Responsibility of Forms. Critical Essays on Music, Art, and Representation. Berkeley/Los Angeles: University of California Press, 1991. English translation: Richard Howard.

BARTHES, Roland. Roland Barthes by Roland Barthes. London: Papermac, 1995. English translation: Richard Howard.

BARTHES, Roland. The Neutral. Lecture Course at the Collège de France (1977-1978). New York: Columbia University Press, 2005. English translation: Rosalind E. Krauss.

CURRAN, Alvin. When I Saw Kosugi Get Into a Large Duffle-Bag with His Guitar. In Arcana V: Music, Magic, and Mysticism. Zorn, John (ed.). New York: Hips Road, 2010, p. 98-103.

CURRAN, Alvin. Shofar Rags. In: Shofar Rags (CD booklet). Zorn, John (ed.). New York: Tzadik, 2013, p. 2-10.

DELEUZE, Gilles - GUATTARI, Félix. A Thousand Plateaus. Capitalism and Schizophrenia. London/ New York: Continuum, 2004. English translation: Brain Massumi.

5 CURRAN, Alvin. When I Saw Kosugi Get Into a Large Duffle-Bag with His Guitar. In Arcana V: Music, Magic, and Mysticism. Zorn, John (ed.). New York: Hips Road, 2010, p. 100-101. 
